\title{
New Pottiaceae Records to the Moss Flora of Libya
}

\author{
Said Ghanem Youssef*, Manal Ibrahim Khalil", Hanaa Shabbara* and Wagieh \\ El-Saadawi* \\ Botany Department, Faculty of Science, Benha University, Benha and "Botany \\ Department, Faculty of Science, Ain Shams University, Cairo, Egypt.
}

\begin{abstract}
DOTTIACEAE includes up to 5,311 species worldwide. It is the largest moss family in Libya with 41 out of a total of 98 species known from this country. Most of the species are quite old records based on collections published before 1932. In this recent work 20 Pottiaceae mosses are reported from Libya including two new records namely; Microbryum rectum (With.) R.H.Zander and Weissia controversa var. crispata (Nees and Hornsch.) Nyholm. Descriptions and illustrations of the two new records together with geographic distribution and brief comments on all taxa are given.
\end{abstract}

Keywords: Pottiaceae, Mosses, Al-Jabal Al- Akhdar, Beida, Zawya Al-Qadima, Libya.

\section{Introduction}

The Plant List includes 5,311 scientific plant names of species rank for the family Pottiaceae (The plant list, 2013). Of these 3,223 are accepted species names belong to 138 plant genera distributed in different parts of the world. Up till now 16 genera and 41 species of Pottiaceae are known from Libya and all are quite old records based on collections published before 1932 except Aloina ambigua (Bruch and Schimp.) Limpr. which is not that old, being recorded by Rungby in 1962, Bizot, in 1973 and Gallego et al. in 1999, besides Didymodon rigidulus Hedw. and D. tophaceus (Brid.) Lisa which were recorded also by Bizot in 1973. Baroni (1892) was the first to mention Pottiaceae from Libya followed by Durand \& Barratte (1910), Zodda (1913, 1914), Bottini (1914) and Pampanini (1917, 1931), etc. (Ros et al., 2013).

Pottiaceae exist mainly in the north of Libya at Tobruk, Chersa, Al Qubbah, Mechili, Shahet, Borgo, Tocra, Tecniz, Tolmetta, Darnah, Susa, Beida (or Bayda), Wadi Kouf, Al Marj, Benghazi, Tripoli and Gharyain on the Mediterranean coast (Fig. 1). There are three other Pottiaceae collection sites mentioned in the literature, i.e. Bosco Zorda, Wadi Balgader and Wadi Sambar but we could not find them on the available geographical maps of Libya.
To prepare a more up to date moss flora of Libya, the first author of this paper made a large number (550) of moss collections, between the years 2004-2008, from five areas in Al-Jabal AlAkhdar (the green mountain) namely: Wadi Kouf (200 specimens), Beida (189 specimens), Shahet (99 specimens), Mas'sa (37 specimens) and Hani'ya (25 specimens).

One-hundred and thirty out of the 200 specimens of Wadi Kouf had been studied in a series of 4 papers (Shabbara \& Ghanem, 2006 and Youssef et al., 2009 a,b and 2017) which resulted in the record of 14 species. Ten of these 14 species (7 Brachytheciaceae, 2 Orthotrichaceae and 1 Fabroniaceae) were then new records to Libya while the other four (3 Brachytheciaceae and 1 Orthotrichaceae) were recorded earlier by Bottini (1914), Zodda (1926) and Pampanini (1931).

The present paper is the fifth in this series pertaining to the mosses of Al-Jabal Al-Akhdar and deals with 28 out of the 189 specimens that were collected from Beida. The 161 specimens remaining from Beida and the specimens of the three other areas (Shahet, Mas'sa and Hani'ya) will be considered in forth coming publications.

\section{Study Area and Materials}

The Al-Jabal Al-Akhdar is a limestone plateau up to $870 \mathrm{~m}$ above sea level with an undulating surface which tips gently to the south, stretches

\#Corresponding author e-mail: msmyes68@yahoo.com

DOI: 10.21608/ejbo.2017.1793.1125

C2018 National Information and Documentation Centre (NIDOC) 
between the longitudes $20^{\circ} 35^{\prime} \mathrm{E}$ to $23^{\circ} 15^{\prime} \mathrm{E}$ and latitudes $30^{\circ} 58^{\prime} \mathrm{N}$ to $32^{\circ} 56^{\prime} \mathrm{N}$ in the North-East of Libya between Benghazi and Darnah (Fig. 2) (Suleiman et al., 2016). This Jabal (mountain) is covered by arching Plateau built of upper Cretaceous and Tertiary sediments of limestone, subordinate dolomites and marls. These sediments were deposited at the southern margin of the Tethys sea.

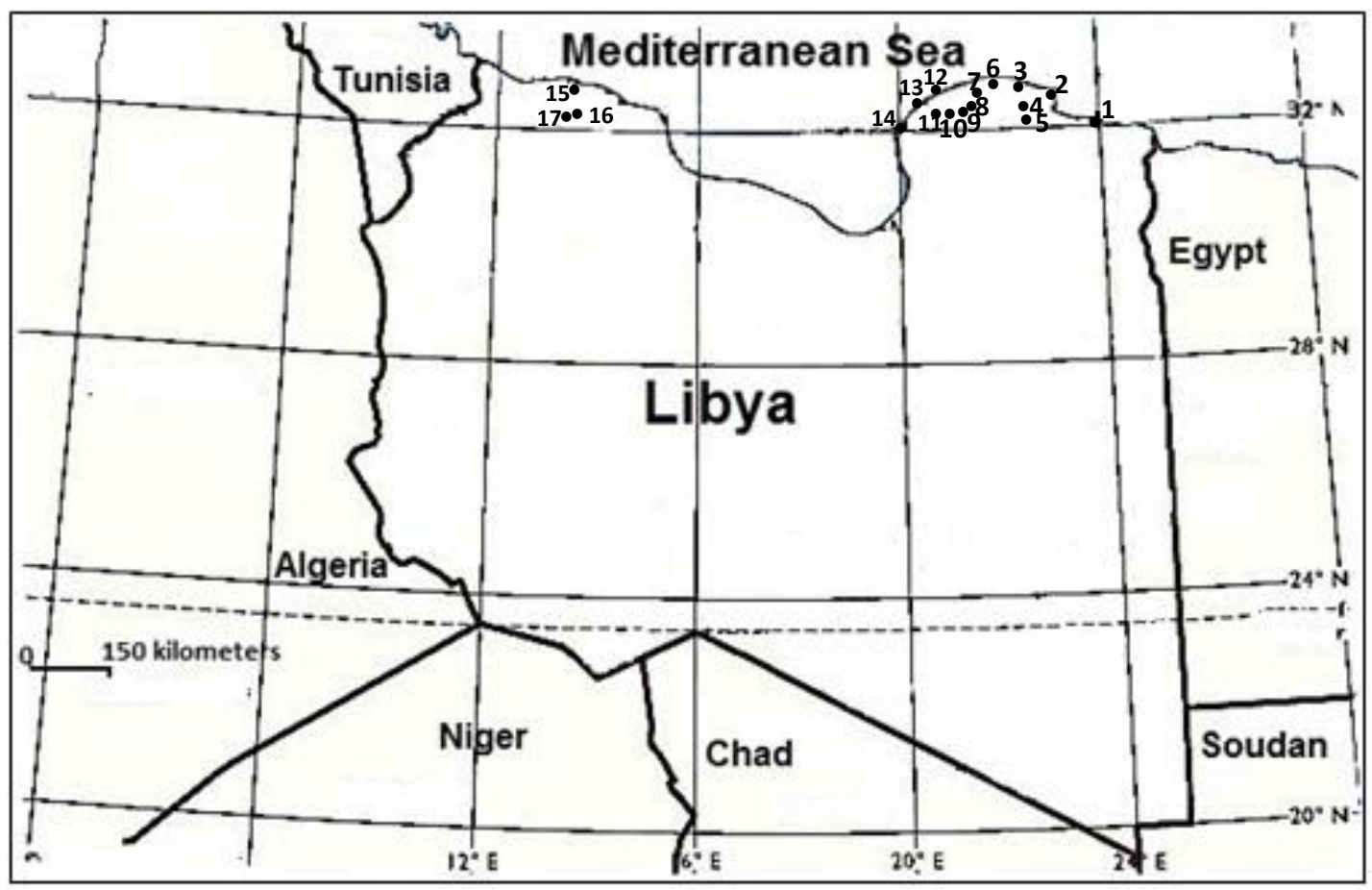

Fig.1. Map showing the sites (old and new) of collections of family Pottiaceae in Libya. 1- Tobruk, 2- Darnah, 3- Chersa, 4- Al Qubbah, 5- Mechili, 6-Susa, 7- Shahet, 8- Beida, 9- Wadi Kouf, 10- Tocra, 11- Al Marj, 12- Tecniz, 13- Tolmetta, 14- Benghazi, 15- Tripoli, 16- Borgo and 17Gharyain.

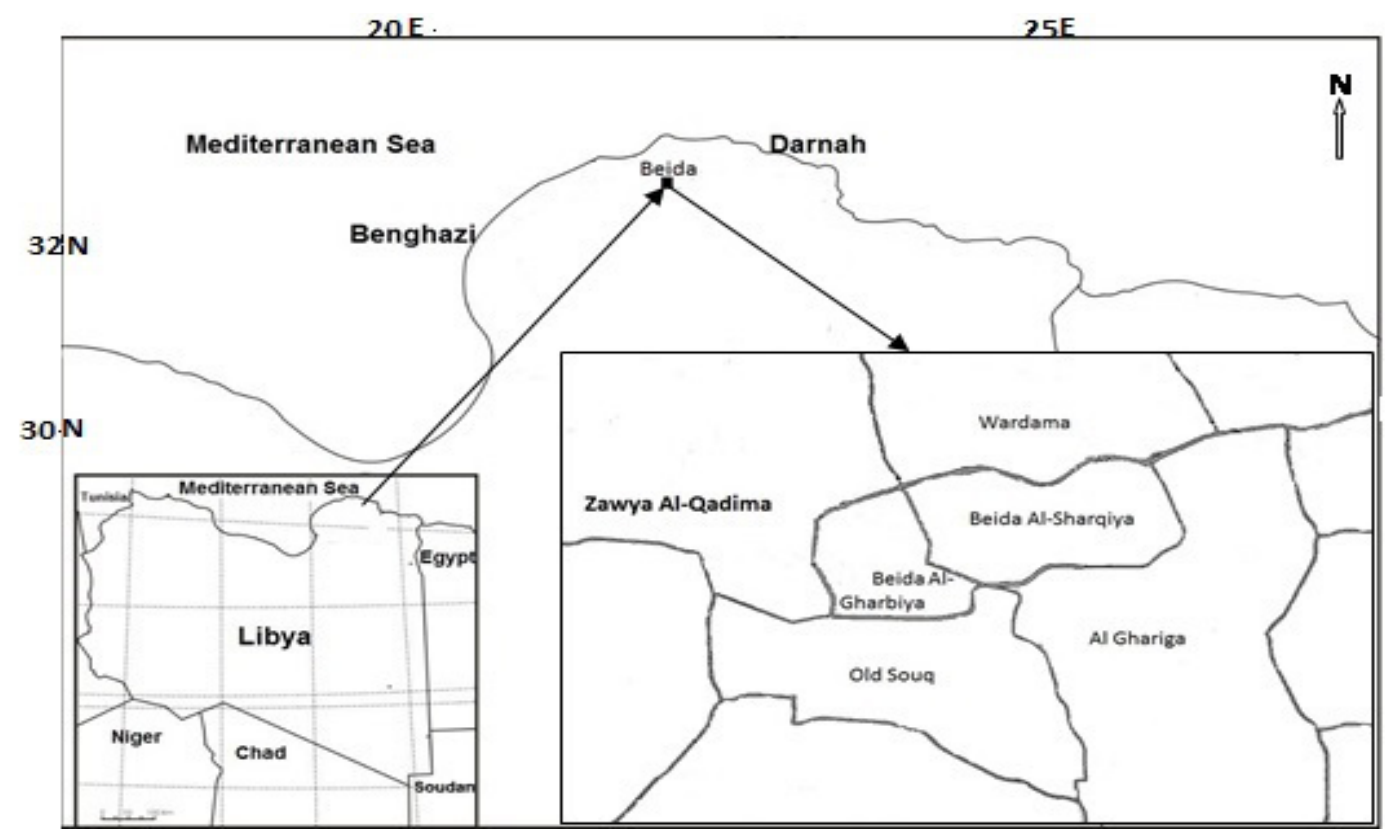

Fig. 2. Map showing the site of the study area (Zawya Al-Qadima) and the other provinces of Beida. 
Beida is located in the plateau of Al-Jabal alAkhdar in the north-east of Libya at an altitude reaching about 625 meters above sea level and between the latitudes $32^{\circ} 45^{\prime} 59^{\prime \prime} \mathrm{N}$ to $32^{\circ} 56^{\prime}$ $39^{\prime \prime} \mathrm{N}$ and longitudes $21^{\circ} 44^{\prime} 30^{\prime \prime} \mathrm{E}$ to $21^{\circ} 54^{\prime}$ $57 " \mathrm{E}$ between Benghazi and Darnah. Beida is considered one of the best towns in Libya in terms of nature and climate, where the climate is mild and cold to cool in the winter, and the average annual rainfall ranges between $550-700 \mathrm{~mm}, 20$ $30 \%$ falling in January. The temperature is $4-13^{\circ} \mathrm{C}$ in winter and $13-27^{\circ} \mathrm{C}$ in summer, while winds are northern in winter but southern and east southern in other seasons. These climate conditions are suitable for a good bryophytes plant cover (Röhlich, 1978).

One-hundred and eighty-nine moss specimens were collected on the $29^{\text {th }}$ and $30^{\text {th }}$ of December, 2004 from different areas of Beida namely: Wardama (42 specimens), Beida Al-Sharqiya (40 specimens), Beida Al-Gharbiya (35 specimens), Zawya Al-Qadima (28 specimens), the Old Souq (25 specimens) and Al Ghariga (19 specimens) (Fig. 2).

The present work deals with the 28 specimens which. were collected from Zawya Al-Qadima (one of the six provinces to which Beida is divided; Fig. 2). Zawya Al-Qadima lies to the west of Beida, at latitudes ca $32^{\circ} 46^{\prime} 05^{\prime \prime} \mathrm{N}$ and longitudes ca $21^{\circ} 42^{\prime} 43^{\prime \prime} \mathrm{E}$, ca 550-600 meters above sea level. Zawya Al-Qadima area consists of clay, rocks and stones with high and low water levels and is rich in arborescent seed plants as: Juniperus phoenicea L., Quercus coccifera L., Pistacia lentiscus L. and Phillyrea latifolia L. The collected mosses were found growing, on shaded coarse soil under trees and between rocks where water flows. Samples were kept in herbarium packets at CAIA (Herbarium, Botany Department, Faculty of Science, Ain Shams University).

\section{Results and Discussion}

After careful study of the 28 specimens of Zawya Al-Qadima, it was found that they include mosses representing six families namely: Brachytheciaceae, Dicranaceae, Fissidentaceae, Funariaceae, Grimmiaceae and Pottiaceae. Only Pottiaceae will be dealt with here while the other remaining families will be considered later. Pottiaceae in the 28 specimens is represented by 20 species. Eighteen of them represent old records to Libya while only two namely: Microbryum rectum
(With.) R.H.Zander and Weissia controversa var. crispata (Nees and Hornsch.) Nyholm. are new records to it. This raised the number of Pottiaceae known from Libya to 43 species and its known moss flora to 100 species. These 43 Pottiaceae species are also highly distributed in different countries of the Mediterranean region (the most common are Tortula muralis Hedw. and Trichostomum crispulum Bruch being recorded in all Mediterranean countries, while the least common is Alonia biforns (De Not.) Delgad.; in 11 countries (Ros et al., 2013).

Geographic distribution, descriptions and comments

Details about the 20 recorded species are given below including; number of gatherings and distribution, while descriptions and illustrations are given for only the two new records. The number following each plant name is the specimen number which is followed by the acronym "YLZ" where $Y=$ Youssef- one of the authors of this paper, $\mathrm{L}=$ Libya and $\mathrm{Z}=$ Zawya Al-Qadima.

\section{Aloina rigida (Hedw.) Limpr}

One gathering (360 YLZ), on clay wet soil in shade under trees.

\section{Distribution}

In Libya; Al Marj, Benghazi, Gharyain and Tripoli (Bottini, 1914 and Pampanini, 1917, 1931); Zawya Al-Qadima-Beida (the present work) .

In the Mediterranean region: In 30 out of 34 countries (Ros et al., 2013).

In the world: Mediterranean region, Australia, Chad, Djibouti, Iraq, Kenya and United States (Haring, 1961; Weber, 1973; Agnew \& Vondráček, 1975; Peck, 1978; McCleary \& Redfearn, 1979; Catcheside, 1980; Mahler, 1980; Zander, 1993; O'Shea, 2006 and Ros et al., 2013).

Crossidium crassinervium (De Not.) Jur

One gathering (361a YLZ), on clay wet limestone soil, in shade under trees.

\section{Distribution}

In Libya; no sites were mentioned; only Libya (Ros et al., 1999); Zawya Al-Qadima-Beida (the present work).

In the Mediterranean region: In 24 out of 34 countries (Ros et al., 1999).

In the world: Mediterranean region, Chad, 
China, Mexico and United States (Tan \& Zhao, 1997; Mahler, 1980; O’Shea, 2006; Delgadillo \& Cárdenas, 2011 and Ros et al., 1999).

\section{C. squamiferum (Viv.) Jur}

One gathering (361b YLZ), on clay wet soil, in shade under trees.

\section{Distribution}

In Libya; Al Marj, Mechili, Tecniz, Bosco Zorda, Tripoli and Gharyain (Bottini, 1914 and Pampanini , 1931); Zawya Al-Qadima-Beida (the present work).

In the Mediterranean region: In 23 out of 34 countries (Ros et al., 1999).

In the world: Mediterranean region, Chad, China, Iraq, and Mongolia (Agnew \& Vondráček 1975; El- Saadawi \& Badawi, 1977; Abramov \& Abramova, 1983; Redfearn \& Wu, 1986; O’Shea, 2006 and Ros et al., 2013).

C. squamiferum (Viv.) Jur. var. pottioideum (De Not.) Mönk

One gathering (361c YLZ), on wet limestone soil, in shade under trees.

\section{Distribution}

In Libya; no sites were mentioned; only Libya (Ros et al., 2013); Zawya Al-Qadima-Beida (the present work).

In the Mediterranean region: In 15 out of 34 countries (Ros et al., 1999).

In the world: Mediterranean region, Iraq, Mongolia and United States (Agnew \& Vondráček 1975; Abramov \& Abramova, 1983; Zander, 2007 and Ros et al., 1999).

\section{Didymodon acutus (Brid.) K.Saito}

Three gatherings (362 YLZ-364 YLZ), on wet limestone soil, in shade under trees.

\section{Distribution}

In Libya; Al Qubbah (Pampanini, 1931), Zawya Al-Qadima-Beida (the present work).

In the Mediterranean region: In 33 out of 34 countries (Ros et al., 1999).

In the world: Mediterranean region, northern Africa, ES Europe, Turkey and United State (Anderson et al., 1990; O’Shea, 2006; Sabovljević, et al., 2008 and Ros et al., 1999).

\section{D. fallax (Hedw.) R.H.Zander}

One gathering (365 YLZ), on wet clay soil, in shade under trees.

\section{Distribution}

In Libya; Gharyain and Wadi Sambar (Bottini, 1914 and Pampanini, 1931); Zawya Al-QadimaBeida (the present work).

In the Mediterranean region: In 32 out of 34 countries (Ros et al., 2013).

In the world: Mediterranean region, Canada, China, Mexico and United States (Redfearn \& Wu, 1986; Zander, 1994, 2007 and Ros et al., 2013).

\section{D. insulanus (De Not.) M.O.Hill}

One gathering (366a YLZ), on wet limestone soil, in shade under trees.

\section{Distribution}

In Libya; Gharyain (Bottini, 1914); Zawya AlQadima-Beida (the present work).

In the Mediterranean region: In 30 out of 34 countries (Ros et al., 2013).

In the world: Mediterranean region, Kenya, Mali and Tanzania (O'Shea, 2006 and Ros et al., 1999).

\section{D. luridus Hornsch}

One gathering (367a YLZ), on wet clay soil, in shade under trees.

\section{Distribution}

In Libya; Al Marj, Darnah, Shahet, Tecniz, Tolmetta, Bosco Zorda, Gharyain and Wadi Kouf, (Bottini, 1914 and Pampanini, 1931); Zawya AlQadima-Beida (the present work).

In the Mediterranean region: In 33 out of 34 countries (Ros et al., 2013).

In the world: Mediterranean region, Chad and United States (Stark \& Castetter, 1982 and O'Shea, 2006 and Ros et al., 2013).

\section{D. vinealis (Brid.) R.H.Zander}

Three gatherings (368 YLZ - 370 YLZ), on wet limestone soil, in shade under trees.

\section{Distribution}

In Libya; Beida, Benghazi, Shahet, Gharyain and Wadi Sambar (Bottini, 1914 and Pampanini, 1917, 1931); Zawya Al-Qadima-Beida (the present work). 
In the Mediterranean region: In 33 out of 34 countries (Ros et al., 1999).

In the world: Mediterranean region, Chain, Java, Malaysia, Philippines, Mexico and United States (Stark \& Castetter, 1982; Redfearn \& Wu 1986; Eddy, 1990; Zander, 1994 and Ros et al., 1999).

Eucladium verticillatum (With.) Bruch and Schimp.

One gathering (371 YLZ), on wet limestone soil, in shade under trees.

\section{Distribution}

In Libya; Darnah, Wadi Kouf, Susa and Wadi Balgader (Pampanini, 1931); Zawya Al-QadimaBeida (the present work) .

In the Mediterranean region: In 32 out of 34 countries (Ros et al., 1999)

In the world: Mediterranean region, Brazil, Canada, Chad, China, Ethiopia, Japan, ,Mali, Mauritania, Rwanda, Mexico and United States (Weber 1973; Saito, 1975; McCleary \& Redfearn, 1979; Redfearn, 1979; Churchill, 1985; Redfearn \& Wu, 1986; Snider, et al., 1986; Noguchi \& Iwatsuki, 1988; Zander, 1994, 2007; Xing-jiang \& Iwatsuki, 1996; O'Shea, 2006; Forzza, 2010 and Ros et al., 1999).

\section{Microbryum davallianum (Sm.) R.H.Zander}

One gathering (366b YLZ), on wet limestone soil, in shade under trees.

\section{Distribution}

In Libya; Darnah (Pampanini, 1931); Zawya Al-Qadima-Beida (the present work) .

In the Mediterranean region: In 30 out of 34 countries (Ros et al., 1999).

In the world: Mediterranean region, Brazil and South Africa (O'Shea, 2006, Forzza, 2010 and Ros et al., 1999).

\section{M. rectum (With.) R.H.Zander}

One gathering (372 YLZ), on wet clay soil, in shade under trees.

\section{Distribution}

In Libya: new record to Libya; Zawya AlQadima-Beida (the present work).

In the Mediterranean region: In 17 out of 34 countries (Ros et al., 1999).
In the world: Mediterranean region, Europe and Turkey (Hill et al., 2006; Sabovljević et al., 2008; Kirmaci \& Agcagil, 2009, Ros et al., 1999 and Hodgetts, 2015).

\section{Description}

Plants brownish, very small (Fig. 3a), up to 1.5 $\mathrm{mm}$ high. Stems up to $0.5 \mathrm{~mm}$ high, rounded in cross section, and with central strand, sclerodermis and hyalodermis not differentiated (Fig. 3j). Leaves crisped when dry, appressed to weakly spreading when moist, lanceolate, ovate to oblonglanceolate, $0.55-0.25 \mathrm{~mm}$ long, $0.27-0.13 \mathrm{~mm}$ wide, plane to broadly concave above mid (Fig. $3 \mathrm{~b}, \mathrm{c})$; apex acute to acuminate; margins recurved, entire to slightly crenulate-papillose above (Fig. 3d,e); costa excurrent, circular in cross section, with only one stereid band and 2 guides, epidermis differentiated ventrally and dorsally (Fig. 3i); upper laminal cells hexagonal, short rectangular to rhomboidal, $8-12 \mu \mathrm{m}$ long, 6-12 $\mu \mathrm{m}$ wide, strongly papillose, evenly thick walled (Fig. 3f,g); basal laminal cells lax, long to short rectangular, 18-30 (60) $\mu \mathrm{m}$ long, 12-18 $\mu \mathrm{m}$ wide, smooth, with thin walls (Fig. 3h). Seta short, $0.7 \mathrm{~mm}$ long; capsule globose to spherical, erect, orange-brown; lid small, conical, persistent (Fig. 3k); peristome absent. Spore $24 \mu \mathrm{m}$ in diameter, yellowish brown, spinulose (Fig. 31).

Microbryum rectum may be confused with M. davallianum (Sm.) R.H.Zander and $M$. starckeanum (Hedw.) R.H.Zander which are also known from Libya. But the cleistocarpous capsule of $M$. rectum distinguishes it easily from these two taxa which have stegocarpous capsules.

\section{M. starckeanum (Hedw.) R.H.Zander}

One gathering (367b YLZ), on wet limestone soil, in shade under trees.

\section{Distribution}

In Libya: Darnah, $\mathrm{Al}$ Qubbah and Benghazi (Pampanini, 1931) Zawya Al-Qadima-Beida (the present work).

In the Mediterranean region: In 29 out of 34 countries (Ros, et al., 1999).

In the world: Mediterranean region and United States (Zander, 2007 and Ros et al., 1999).

Pseudocrossidium hornschuchianum (Schultz)
R.H.Zander
One gathering (373a YLZ), on wet limestone soil, in shade under trees. 


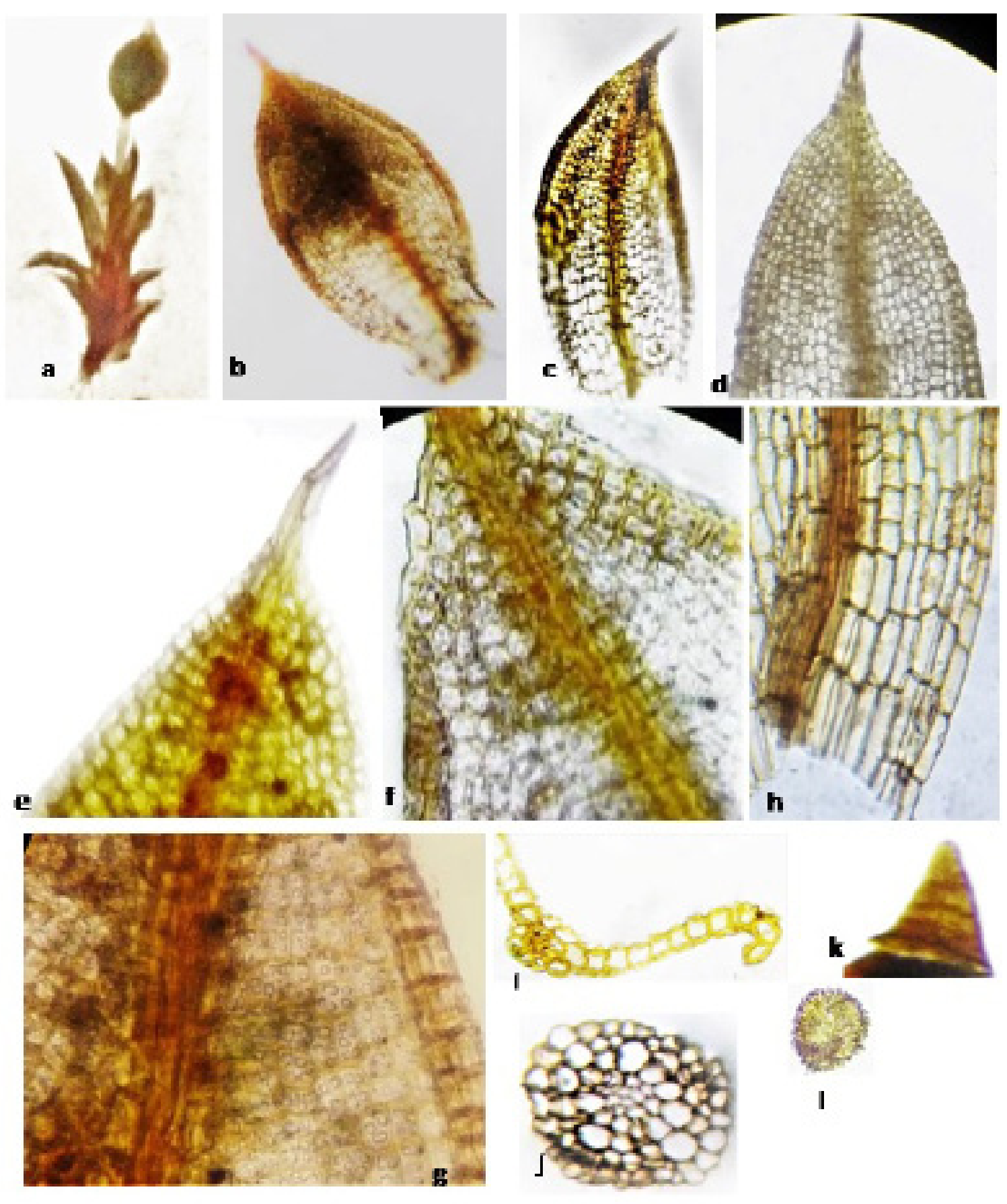

Ereter

Fig. 3. a-l, Microbryum rectum: a- Gametophyte carrying sporophyte. b, c- Leaves. d, e - Leaf apices. f- Marginal cells bellow leaf apex. g- Upper laminal cells. h- Cells at leaf base. i- Part of a cross section of a leaf. $\mathbf{j}$ - Cross section of a stem. $k$ - Lid. l- Spore.

Scale bar $=0.6 \mathrm{~mm}$ (a), $0.07 \mathrm{~mm}$ (b), $0.08 \mathrm{~mm}$ (c), $54 \mu \mathrm{m}$ (d), $36 \mu \mathrm{m}$ (e), $22.5 \mu \mathrm{m}$ (f), $22.5 \mu \mathrm{m}$ (g), $33.3 \mu \mathrm{m}$ (h), $29 \mu \mathrm{m}$ (i), $72 \mu \mathrm{m}$ (j), $36 \mu \mathrm{m}(\mathrm{k}), 4.7 \mu \mathrm{m}$ (l). 


\section{Distribution}

In Libya: Gharyain, Bosco Zorda and Wadi Darnah (Botanini, 1914 and Pampanini, 1931); Zawya Al-Qadima-Beida (the present work).

In the Mediterranean region: In 31 out of 34 countries (Ros et al., 1999)

In the world: Mediterranean region Canada, Ethiopia and South Africa (O'Shea, 2006 ; Zander, 2007 and Ros et al., 1999).

\section{Timmiella barbuloides (Brid.) Mönk.}

Four gatherings (373b YLZ, 374 YLZ-376 YLZ), on wet limestone soil, in shade under trees.

\section{Distribution}

In Libya: Al Marj, Tobruk, Tocra and Wadi Sambar (Pampanini, 1931); Zawya Al-QadimaBeida (the present work).

In the Mediterranean region: In 26 out of 34 countries (Ros et al., 1999)

In the world: Mediterranean region, Brazil, Chad, Djibouti, Egypt, Eretria and Sudan (El-Saadawi \& Badawi, 1977; O’shea, 2006; Forzza, 2010 and Ros et al., 1999).

\section{Tortella tortuosa (Hedw.) Limpr.}

Two gatherings (366c YLZ, 377 YLZ), on wet clay soil, in shade under trees.

\section{Distribution}

In Libya: No sites were mentioned; only Libya (Ros et al., 1999); Zawya Al-Qadima-Beida (the present work).

In the Mediterranean region: In 27 out of 34 countries (Ros et al., 1999).

In the world: Mediterranean region: Canary Islands, China, Hawaiian Isl, Iraq, Japan, Malawi, Mexico, Mongolia, and United States (Hilferty, 1960; Lampton, 1970; Lawton, 1971; Breil, 1973; Weber, 1973; Agnew \& Vondráček, 1975; Saito, 1975; Peck, 1978; Eversman \& Sharp, 1980; Ketchledge, 1980; Mahler, 1980; Stark \& Castetter, 1982; Abramov \& Abramova, 1983; Crum, 1983; Zander, 1994; Xingjiang \& Iwatsuki, 1996; Staples et al., 2004; O’Shea, 2006; Delgadillo \& Cárdenas, 2011 and Ros et al., 1999).

Tortula marginata (Bruch and Schimp.)Spruce

One gathering (378a YLZ), on wet limestone soil, in shade under trees.

\section{Distribution}

In Libya: Beida, Tobruk, Susa, Darnah and Wadi Balgader (Bottini, 1914 and Pampanini, 1931); Zawya Al-Qadima-Beida (the present work).

In the Mediterranean region: In 29 out of 34 countries (Ros et al., 1999).

In the world: Mediterranean region, Caribbean, Iraq, Jamaica and New Zealand (Crum \& Bartram, 1958; Wijk et al., 1959-1969; Agnew \& Vondráček, 1975; Beever et al., 1992 and Ros et al., 1999).

\section{T. muralis Hedw.}

One gathering (378b YLZ), on wet limestone, in shade under trees.

\section{Distribution}

In Libya: Shahet, Borgo, Bosco Zorda, Tecniz, Al Marj, Tobruk, Darnah, Beida and Tropili (Bottini, 1914 and Pampanini, 1931); Zawya Al-QadimaBeida (the present work) .

In the Mediterranean region: In all 34 countries (Ros et al., 2013).

In the world: Mediterranean region, Australia, Brazil, Canada, Egypt, Iraq, Japan, Namibia, New Zealand, Philippines, South Africa and United States (Haring, 1961; Lampton, 1970; Lawton, 1971; Breil, 1973; Agnew \& Vondráček, 1975; Saito, 1975; ElSaadawi \& Badawi, 1977; Peck, 1978; Catcheside, 1980; Ketchledge, 1980; Mahler, 1980; Mahler \& Mahler, 1980; Iwatsuki, 1991; Magill, 1981 [1982]; Tan \& Iwatsuki, 1991; Beever et al., 1992; Zander, 2007; Forzza, 2010 and Ros et al., 1999).

\section{Trichostomum brachydontium Bruch}

One gathering (379 YLZ), on wet limestone, in shade under trees.

\section{Distribution}

In Libya: No sites were mentioned; only Libya (Ros et al., 1999); Zawya Al-Qadima-Beida (the present work).

In the Mediterranean region: In 32 out of 34 countries (Ros et al., 1999)

In the world: Mediterranean region, Angola, Azores, Brazil, Canada, Caribbean, China, Colombia, Costa Rica, Guatemala, Hawaiian Isl, India, Japan, Kenya, Madeira, Mexico, Namibia, New Zealand, South Africa, Swaziland, and United States (Wijk et al., 1959-1969; Gangulee, 1972; Saito, 1975; Noguchi \& Iwatsuki, 1988; Magill, 1981 [1982]; Norris \& Koponen, 1989; Beever et al., 1992; Zander,1994, 2007; Xing-jiang 
\& Iwatsuki, 1996; Staples et al., 2004; Forzza, 2010; Delgadillo \& Cárdenas, 2011 and Ros et al., 2013).

Weissia controversa var. crispata (Nees and Hornsch.) Nyholm

One gathering (380 YLZ), on wet limestone, in shade under trees.

Distribution

In Libya: New record to Libya; Zawya AlQadima-Beida (the present work).

In the Mediterranean region: 18 out of 34 countries (Ros et al., 2013).

In the world: Mediterranean region and Iraq (Agnew \& Vondráček, 1975 and Ros et al., 2013)

\section{Description}

Plants green to light brown below (Fig. 4a,b), $4 \mathrm{~mm}$ high. Stems $1.5 \mathrm{~mm}$ high, rounded in cross section, and with central strand, sclerodermis little differentiated (Fig. 4k). Leaves crisped to incurved when dry, appressed to weakly spreading when moist, becoming larger upward, narrowly long lanceolate to oblong lanceolate, $1.6-1.9 \mathrm{~mm}$ long, $0.15-0.3 \mathrm{~mm}$ wide, gradually tapering from an oblong base (Fig. 4c); apex acute, short mucronate (Fig. 4d); margins plane, incurved to \pm involute toward apex, entire at base to crenulate-papillose above; costa 36-65 $\mu \mathrm{m}$ wide, excurrent, semicircular to \pm flattened in cross section, with ventral and dorsal stereid bands and 2-8 guides, epidermis differentiated ventrally and little differentiated dorsally (Fig. 4h-j), with quadrate papillose cells on upper ventral surface of costa, elongate papillose cells on dorsal surface of costa (Fig. 4f); upper laminal cells quadrate, hexagonal, 6-12 $\mu \mathrm{m}$ long, $6 \mu \mathrm{m}$ wide, strongly papillose, evenly thick walled (Fig. 4e); basal laminal cells linear to long rectangular, 24-30 $\mu \mathrm{m}$ long, 6-12 $\mu \mathrm{m}$ wide, smooth, with thin walls (Fig. 4g). Seta $6 \mathrm{~mm}$ long; capsule elliptical, with small mouth, erect, orangebrown, slightly furrowed when dry (Fig.4m); lid long and narrowed, conical, persistent (Fig. 41); peristome rudimentary (Fig. 4n). Spore, brown, papillose, 18 $\mu \mathrm{m}$ in diameter (Fig. 4o).

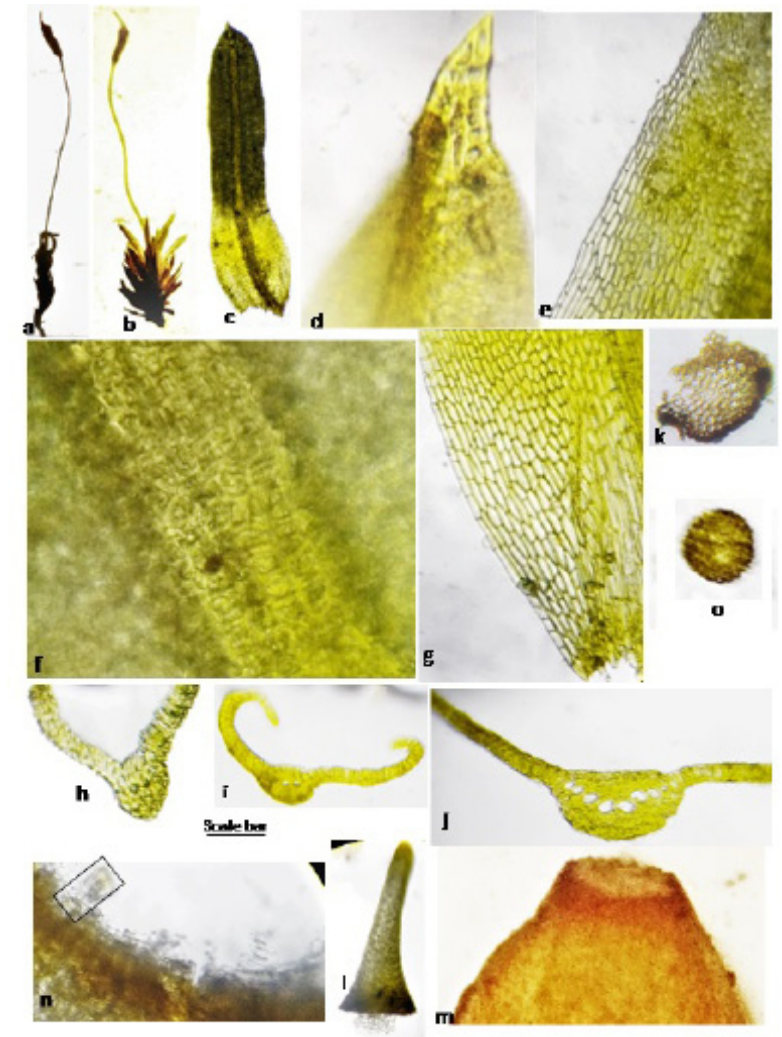

Fig. 4. a-o, Weissia controversa var. crispata: a- Dry gametophyte carrying sporophyte. b- Wet gametophyte carrying sporophyte. c- Leaf. d- Leaf apex. e- Upper marginal cells. f- Ventral surface of costa. g- Cells at leaf base. $h, i, j$ - Different cross sections of a leaf. $k$ - Cross section of a stem. l- Lid. m- Capsule mouth. n- Part of peristome teeth. o- Spore.

Scale bar $=0.2 \mathrm{~mm}$ (a) \& (b), $0.33 \mathrm{~mm}$ (c), $6.5 \mathrm{~mm}$ (d), $42 \mu \mathrm{m}$ (e), $20 \mu \mathrm{m}$ (f), $63 \mu \mathrm{m}$ (g), $30 \mu \mathrm{m}$ (h), $51 \mu \mathrm{m}$ (i), $25.7 \mu \mathrm{m}$ (j), $65 \mu \mathrm{m}$ (k), $226 \mu \mathrm{m}$ (1), $147 \mu \mathrm{m}$ (m), $24 \mu \mathrm{m}$ (n), $4.5 \mu \mathrm{m}$ (o). 
Weissia controversa var crispata is relatively similar in form to $W$. condensa (Voit) Lindb which was recorded previously (Zodda, 1913) from Libya. But the long lanceolate leaf, narrower costa at base and capsule with rudimentary peristome distinguishes it easily from $W$. condensa.

Investigation of the rest of the collected moss specimens is going on at present and there is great hope in making many new records under different families as well as in confirming many of the old ones.

\section{References}

Abramov, I.I. and Abramova, A.L. (1983) Konspekt flor'i mhov Mongol'skoj Narodnoj Respubliki. Biol. Resursy Prir. Uslov. Mongol'sk. Narod. Respubl. 17. 221 pp.

Agnew, S. and Vondráček, M. (1975) A moss flora of Iraq. Feddes Repert, 86, 341-489.

Anderson, L.E., Crum, H.A. and Buck, W.R. (1990) List of mosses of North America north of Mexico. Bryologist, 93, 448-499.

Baroni, E. (1892) Spora algune crittogame africane raccolte presso Tripoli di barbeira dal prof. Raffaelo Spigai. Bollettino della Societd Botanica Italiana, 239-243.

Beever, J., Allison, K.W. and Child, J. (1992) "Mosses New Zealand" (2 ${ }^{\text {nd }}$ ed.), 214 pp. University of Otago Press, Dunedin.

Bizot, M. (1973) Mouses africaines récoltées par M. Denes Balazs. Acta Botanica Academiae Scientiarum Hungaricae, 18, 7-28.

Bottini, A. (1914) Muschi di Libia. Bollettino di Studi ed Injormazioni R. Giardino Coloniale. Palermo, 1, 1-7.

Breil, D.A. (1973) "Mosses of Virginia: A Provisional Key to the Genera". Longwood College, $21 \mathrm{pp}$.

Catcheside, D.G. (1980) "Mosses of South Australia. Handb. Fl. and Fauna S. Australia" 364 pages.

Churchill, S.P. (1985) A synopsis of the Kansas mosses with keys and distribution maps. Univ. Kansas Sci. Bull. 53, 1-64.

Crum, H.A. (1983) "Mosses Great Lakes Forest" (3 ${ }^{\text {rd }}$ ed.) $417 \mathrm{pp}$. University Herbarium, University of Michigan, Ann Arbor.

Crum, H.A. and Bartram, E.B. (1958) A survey of the moss flora of Jamaica. Bull. Inst. Jamaica, Sci. Ser. 8, 90 .

Delgadillo Moya, C. and Cárdenas Soriano, Á. (2011) Bryophyta (Musci). In: "Florist. Oaxaca. Universidad Nacional Autónoma de México", A. J. García-Mendoza and J.A. Meave Divers (Ed.), 137-148, color photos on pp. 65-66. Ciudad Universitaria.

Durand, E. and Barratte, G. (1910) Florae Libycae Prodromus ou Catalogue Raisonné des Plantes de Tripolitaine. Genève, Romet.

Eddy, A. (1990) Leucobryaceae to Buxbaumiaceae Handb. Males. Mosses 2. [iv] +256 pages.

El-Saadawi, W. and Badawi, A. (1977) The moss flora of Egypt. I. Order Pottiales. Publ. Cairo Univ. Herb. 7-8, 181-206.

Eversman, S. and Sharp, A.J. (1980) First checklist of Montana mosses. Proc. Montana Acad. Sci. 39, $12-24$.

Forzza, R.C. (2010) Lista de espécies Flora do Brasil. Jardim Botânico do Rio de Janeiro, Rio de Janeiro.

Gallego, M.T., Cano, M.J., Ros, R.M. and Guerra, J., (1999) The genus Aloina (Pottiaceae, Musci) in the Mediterranean region and neighbouring areas. Nova Hedwigia, 69(1-2), 173-194.

Gangulee, H.C.( 1972) "Mosses E. India" 3. Pp. (xiv$\mathrm{xix})+\mathrm{xv}+567-830$. Privately published, Calcutta.

Haring, I. M. (1961) A checklist of the mosses of the State of Arizona. Bryologist, 64, 222-240.

Hilferty, F.J. (1960) The mosses of Massachusetts. A county catalogue with annotations. Rhodora, 62, 145-173.

Hill, M.O., Bell, N., Bruggeman-Nannenga, M.A., Brugués, M., Cano, M.J., Enroth, J., Flatberg, K.I., Frahm, J.P., Gallego, M.T., Garilleti, R., Guerra, J., Hedenäs, L., Holyoak, D.T., Hyvönen, J., Ignatov, M.S., Lara, F., Mazimpaka, V., Muñoz, J. and Söderström, L. (2006) An annotated checklist of the mosses of Europe and Macaronesia. Journal of Bryology, 28, 198-267.

Hodgetts, N.G. (2015) Checklist and country status of European bryophytes towards a new Red List for Europe. (C) National Parks and Wildlife Service.

Iwatsuki, Z. (1991) "Catalog of the Mosses of Japan" 182 pp. Hattori Botanical Laboratory, Nichinan.

Ketchledge, E.H. (1980) Revised checklist of the moses of New York State. New York State Mus. Bull. 440. 
Kirmaci, M. and Agcagil, E. (2009) The Bryophyte flora in the Urban area of Ayden (Turkey). International Journal of Botany. 5(3), 216-225.

Lampton, R.K. (1970) Mosses of Georgia. A check list of species which have been collected within the State. Bull. Georgia Acad. Sci. 28, 81-98.

Lawton, E. (1971) Moss Fl. Pacif. N.W. xiii + 362 pp. +195 pl. Hattori Botanical Laboratory, Nichi-nan, Japan.

Magill, R.E. (1981) [1982] Sphagnaceae to Grimmiaceae. Part 1, Mosses. Fascicle 1 SphagnaceaeGrimmiaceae. Pp. xv + 1-291. In Fl. S. Africa, Bryophyta. Botanical Research Institute, Pretoria.

Mahler, W.F. (1980) The Mosses of Texas: A manual of the flora with sketches SMU Herbarium. pp. 1-147.

Mahler, B.D. and Mahler, W.F. (1980) Checklist of mosses of Oklahoma. Bryologist, 83, 202-208.

McCleary, J.A. and Redfearn, J.P.L. (1979) Checklist of the mosses of Illinois. Trans. Illinois State Acad. Sci. 72, 28-51.

Noguchi, A. and Iwatsuki, Z. (1988) Illustrated Moss Flora of Japan 2. pp. 243-491, index. Hattori Botanical Laboratory, Nichinan.

Norris, D.H. and Koponen, T. (1989) Bryophyte flora of the Huon Peninsula, Papua New Guinea. XXVIII. Pottiaceae (Musci). Acta Bot. Fenn. 137, 81-138.

O'Shea, B.J. (2006) Checklist of the mosses of subSaharan Africa (version 5, 12/06). Trop. Bryol. Res. Rep. 6, 1-252.

Pampanini, R. (1917) Plante di Bengasi e del suo Territorio raccolte dal Rev. P.D. Vito Zanon della Missione del PP. Giuseppini al Fuehat. Nuovo Giornale Botanico Italiano, 24. 113-171.

Pampanini, R. (1931) Prodromo della Flora Cirenaica. Forli.

Peck, J.H. (1978) A restatement of Conard's Iowa bryophyte flora with modern nomenclature, additional reports, and county dot maps Contr. Univ. Wisconsin-La Crosse Herb. 21, 90.

Redfearn, Jr., P.L. (1979) Bryophytes of the Interior Highlands of North American XVI. Species of the Ozark National Forest, Sylamore Division, and adjacent areas in Stone County, Arkansas. Bryologist 82, 483-486.

Redfearn, P.L.J. and Wu, P.C. (1986) Catalog of the mosses of China. Ann. Missouri Bot. Gard. 73, 177-208.
Röhlich, P. (1978) Geological development of Jabal AlAkhdar, Libya. Int. J. Earth Sci. 67, 401-412.

Ros, R.M., Cano, M.J. and Guerra, J. (1999) Bryophyte checklist of Northern Africa. Journal of Bryology, 21, 207-244.

Ros, R.M., Mazimpaka, V., Abou-Salama, U., AleffI, M., Blockee, T.L., Brugués, M., Cros, R.M., Dia, M.G., Dirkse, G.M., Draper, I., El-saadawi, W., Erda, A., Ganeva, A., Gabriel, R., González-mancebo, J.M., Granger, C., Herrnstadt, I., Hugonnot, V., Khalil, K., Kürschner, H., Losada-lima, A., Luís, L., Mifsud, S., Privitera, M., Puglisi, M., Sabovljeić, M., Sérgio, C., Shabbara, H.M., Sim-sim, M., Sotiaux, A., Tacchi, R., Vanderpoorten, A. and Werner, O. (2013) Mosses of the Mediterranean, an annotated checklist. Cryptogamie, Bryologie, 34(2), 99-283.

Rungby, S. (1962) A contribution to the bryophytic flora of Spain and Morocco, especially the area between Gandia and Alcoy. Botaniska Notiser, 115, 61-64.

Sabovljević, M., Natcheva, R., Dihoru, G., Tsakiri, E., Dragićević, S., Erdağ, A. and Papp, B. (2008) Check-list of the mosses of SE Europe. Phytologia Balcanica, 14(2), 207-244.

Saito, K. (1975) A monograph of Japanese Pottiaceae (Musci). J. Hattori Bot. Lab. 39, 373-537.

Shabbara, H.M. and Ghanem S.Y. (2006) Fabronia Raddi (Musci) in Libya. Egyptian Journal of Biology, 8, 100-105.

Snider, J.A., Studlar, S.M. and Medley, M. (1986) A Checklist of Bryophytes of Kentucky. 32 pp.

Suleiman, B.M., Mohamed, M., Hamad, S., Elmehd, Y.S. (2016) Assessment of forest and Juniperus phoenicea decline in Al Jabal Al Akhdar using NDVI-Remote sensing and GIS data (2006-2013) International Journal of Remote Sensing Applications (IJRSA), 6 , 159-172.

Staples, G.W., Imada, C.T., Hoe, W.J.and Smith, C.W. (2004) A revised checklist of Hawaiian mosses. Trop. Bryol. 25, 35-70.

Stark, L.R. and Castetter, R.C. (1982) A preliminary list of bryophytes from the Organ Mountains, New Mexico. Bryologist, 85, 307-311.

Tan, B.C. and Iwatsuki, Z. (1991) A new annotated Philippine moss checklist. Harvard Pap. Bot. 3, $1-64$.

Tan, B.C. and Zhao, J.C. (1997) New moss records and range extensions of some xeric and alpine moss species in China. Cryptog. Bryol. Lichénol. 18, 207-212. 
Weber, W.A. (1973) Guide to the Mosses of Colorado. Occasional Paper 6. Institute of Arctic and Alpine Research, Univ. of Colorado, Boulder.

Wijk, R. van der, Margadant, W.D. and Florschutz, P. A. (1959-1969) Index Muscorum Vol. 1--5. Regnum Veg. 17, 26, 33, 48, 65 .

Xing-jiang, L. and Iwatsuki, Z. (1996) Studies on Chinese Pottiaceae (I): Subfamilies Timmielloideae, Chionolomoideae and Trichostomoideae. Hikobia 12, 25-36.

Youssef, S.G.M., Abd-el-razik Khaled, S. and Hamad, R.B. (2009a) Orthotrichum schimperi Hammar a new record to Libya. Research Journal of Forestry 3(4), 152-158.

Youssef, S.G.M., Abd-el-razik Khaled, S. and Hamad, R.B. (2009b) Zygodon Hook. ex Taylor a new record to Libya. Pakistan Journal of Biological Sciences, 12(24), 1571-1575.

Youssef, S.G.M., Khalil, M.I., Shabbara, H. and ElSaadawi, W. (2017) Seven Brachytheciaceae (Musci) species new to Libya. Egyptian Journal of Botany, 57(3), 605-619.
Zander, R. H. (1993) Genera of the Pottiaceae: Mosses of harsh environments. Bull. Buffalo Soc. Nat. Sci. 32. 378 .

Zander, R.H. (1994) Tortella. In:"Moss Flora of Mexico" A. J. Sharp et al. (Ed.), Mem. New York Bot. Gard. Vol. 69, pp. 235-238.

Zander, R.H.(2007) Pottiaceae. In: "Flora of North America" Editorial Committee (Ed.). Vol. 27. pp. 476-642. New York and Oxford: Oxford University Press.

Zodda, G. (1913) Musci Tripolitani a R. Pampanini anno 1913 lecti. Nuovo Giornale Botanico Italiano 20, 174-178.

Zodda, G. (1914) Manipolo di Briofite della Tripolitania. Bolletino dell'Orto Botanico della R. Universita di Napoli, 4, 205-209.

Zodda, G. (1926) Di alcune briofite della Cirenaica raccolte dal Prof. Cavara. Bolletino dell'Orto Botanico della R. Universita di Napoli, 8, 235-238.

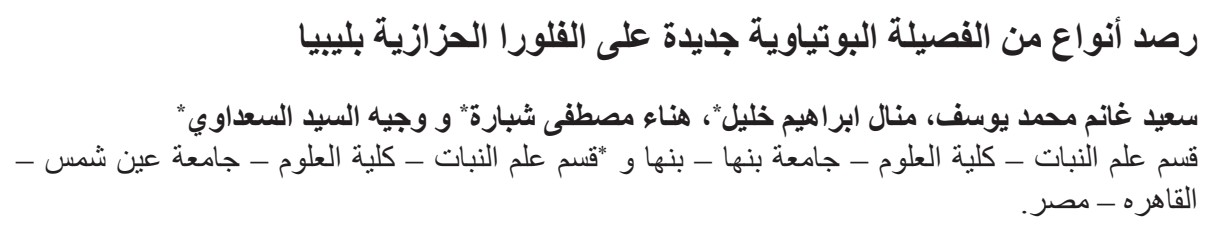

تحتوي الفصيلة البوتياوية على ما يصل إلى 5,311 نو عا منتشرة في جميع انحاء العالم. وهي أكبر فصيلة من

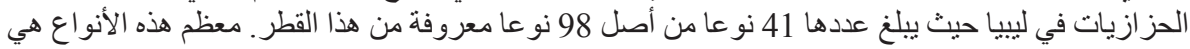

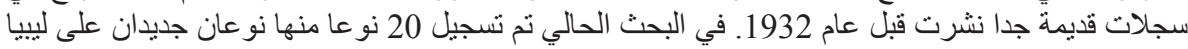
Microbryum rectum (With.) R.H.Zander and Weissia controversa var. crispata همان في ونسيفات (Nees and Hornsch.) Nyholm وتعليقات موجزة على جميع الأنواع التي تم رصدها. 